\title{
Unleashing the power of p53: lessons from mice and men
}

\author{
Masha V. Poyurovsky and Carol Prives ${ }^{1}$ \\ Department of Biological Sciences, Columbia University, New York, New York 10027, USA
}

It is well established that many forms of cellular stress activate the tumor suppressor p53 with ensuing cellular outcomes such as arrest, senescence, or death (Prives and Hall 1999; Vousden and Lu 2002). Although not yet fully understood, each of these is likely in some contexts to be required for $\mathrm{p} 53$ to suppress tumorigenesis (Vousden and Prives 2005). It follows that in the absence of such stress signals, there is also a requirement to keep p53 under tight control until needed. It is now clear that this is largely accomplished by its negative regulator, $\mathrm{Mdm} 2$, an E3 ubiquitin ligase that binds to p53 and can both prevent p53 from functioning effectively as a transcriptional activator and target it for proteasomal degradation (Iwakuma and Lozano 2003). Mdm2 works with another homologous protein, MdmX, that can also down-regulate the transcription function of but cannot degrade p53 (Marine and Jochemsen 2005). There are now several published experiments supporting the importance of maintaining the p53-Mdm2-MdmX circuitry, perhaps the most compelling being the fact that it is not possible to produce viable Mdm2- or Mdmx-null mice unless either are generated in a p53-null background (Jones et al. 1995; Montes de Oca Luna et al. 1995; Parant et al. 2001; Migliorini et al. 2002). Understanding the relationship between these genes is not merely an academic question (even though as such it is a fascinating one); about half of all human tumors express wild-type p53, and a significant proportion of these cancers overexpress Mdm2 (Momand et al. 2000). Therefore, finding ways to prevent down-regulation of $\mathrm{p} 53$ by $\mathrm{Mdm} 2$ in tumors without affecting normal cells is a highly sought therapeutic goal. Recent studies in mice and human patients including one in the previous issue (Mendrysa et al. 2006) of Genes \& Development have brought important new insight to the potential success of such treatment approaches.

\section{When a little bit of $M d m 2$ is just right}

In order to address the question of the extent of the regulation of $\mathrm{p} 53$ by $\mathrm{Mdm} 2$ in the context of normal tissue,

${ }^{1}$ Corresponding author.

E-MAIL clp3@columbia.edu; FAX (212) 865-8246.

Article and publication are at http://www.genesdev.org/cgi/doi/10.1101/ gad.1397506.
M. Perry and colleagues set out to generate a conditionally null allele of $m d m 2$ by engineering two Cre recombination sites (lox $P$ ) flanking the key coding exons of mdm2 (exons 7-9) (Mendrysa et al. 2003). Their experimental setup was designed to remove these central coding exons following Cre-induced recombination, thus yielding a phenotypically null $m d m 2^{\Delta 7-9}$ allele. A third lox $P$ site had been introduced $5^{\prime}$ to the puromycin-resistance cassette, in order to allow for its removal following targeting. Mice generated from the $m d m 2^{+/ p u r o}$ ES cell lines were assessed for the functionality of the puro allele. This was done by breeding these mice to animals with one wild-type and one null allele of $m d m 2$ $\left(m d m 2^{+/ \Delta 7-12}\right)$. Since they could generate $\mathrm{p} 53^{+/+}$mice carrying both one null mdm2 allele and one puro allele $\left(m d m 2^{\text {puro/s7-12 }}\right)$, this meant that the puro allele of $m d m 2$ is functionally active, as they had avoided the embryonic lethality that ensues when there is no Mdm2 (i.e., with two null alleles). However, upon closer examination of the mice with the $m d m 2^{\text {puro/ } / 4-12}$ genotype, it was realized these mice were not born with the expected Mendelian distribution and, in fact, the $m d m 2^{\text {puro/s7-12 }}$ animals that were generated were $\sim 15 \%-20 \%$ percent smaller in size when compared with the wild-type cohort. Indeed, the $m d m 2^{\text {puro/ } / 7-12}$ animals had $\sim 70 \%$ reduced amounts of both Mdm2 mRNA and protein, indicating that the introduction of the puro cassette into the noncoding region of $m d m 2$ had unexpectedly dampened the levels of expression of the wild-type mdm2 allele. To their credit, the authors realized that this serendipitous result could provide an in vivo experimental system for careful study of the effects of down-regulation of wildtype Mdm2 on p53.

Not only did the $m d m 2^{\text {puro/s7-12 }}$ mice show a reduction in body size, upon careful subsequent analysis several additional characteristics were observed. In particular, they had multiple defects in their hematopoietic lineages with deficiencies in their B-cell development and reduced numbers of lymphoid cells in their spleen, thymus, and bone marrow. Furthermore, their lymphocytes displayed a significant increase in p53-dependent apoptosis that was rescued completely by deletion of $p 53$ (i.e., it was not observed in mice that were simultaneously $p 53$ null). These observations demonstrate that $\mathrm{Mdm} 2$ is a central regulator of p53-mediated apoptosis during lymphopoiesis. 
One of the key observations about the $m d m 2^{\text {puro/s7-12 }}$ mice was that there was a significant increase in p53 transcription function observed in all of the tissues tested (Mendrysa et al. 2006). The increase in transcriptional activity did not coincide with changes in p53 nuclear localization, or its phosphorylation on Ser18 (analogous to human p53 Ser15), a residue that is phosphorylated upon multiple forms of stress. Lower Mdm2 protein levels in these mice were also correlated with accumulation of p21 mRNA and protein and increased apoptosis (Mendrysa et al. 2003).

Of note is the fact that mice expressing the hypomorphic allele of $m d m 2$ had significantly elevated response to whole body irradiation-the $m d m 2^{\text {puro/ } / 7-12}$ mice died rapidly following $10 \mathrm{~Gy}$ of whole body irradiation, and this mortality was completely abrogated by the concomitant deletion of $p 53$, once again highlighting the centrality of $\mathrm{Mdm} 2$ for regulation of $\mathrm{p} 53$.

Having demonstrated largely if not exclusively p53dependent phenotypes of the hypomorphic allele of $m d m 2$, Mendrysa et al. (2006) went on to exploit this experimental system to further examine the physiological consequences of $m d m 2$ down-regulation. By crossing animals containing either the wild-type, hypomorphic, or null mdm2 allele, they were able to generate different lines of mice expressing a range of $\mathrm{Mdm} 2$ protein levels

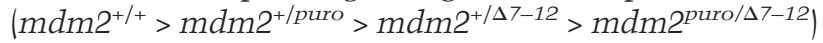
(Mendrysa et al. 2003). Based on their previous results that an $\sim 70 \%$ reduction in $\mathrm{Mdm} 2$ levels leads to the up-regulation of p53 functions, the authors hypothesized that such activation could lead to the inhibition of tumorigenesis with little adverse effects on the animal. They addressed this hypothesis by crossing the mice described above expressing different subphysiological levels of Mdm2 with mice that have one mutant APC allele (these animals develop spontaneous intestinal adenomas). The results showed that even a subtle $(-20 \%)$ reduction in Mdm2 levels led to a significant reduction in intestinal adenoma formation, while down-regulation of Mdm2 (to $\sim 30 \%$ of wild type) reduced the number of such tumors by a factor of $>16$.

These hallmarks of heightened p53 activity did not coincide with an overall increase in p53 protein levels, leading the authors to conclude that in normal tissues, $\mathrm{Mdm} 2$ primarily regulates the activity of $\mathrm{p} 53$ and may have only a minimal effect on $\mathrm{p} 53$ protein stability. They further speculated that this could possibly be due to the fact that the two Mdm2 activities toward p53 /repression and degradation) are independently regulated both in a tissue-specific manner as well as following stress response (Mendrysa et al. 2003). Lesser amounts of Mdm2 protein may be required to maintain low levels of p53 in cells and tissues than are required to inhibit the function of p53. Even as little as $30 \%$ of the wild-type levels of Mdm2 may be sufficient for its ubiquitin ligase enzymatic activity (stoichiometric amounts of enzyme and substrate are generally not required), whereas inhibition of p53 transcription by Mdm2 would likely involve greater quantities of $\mathrm{Mdm} 2$ (perhaps due to the necessity for continuous protein-protein interaction) and therefore would be more sensitive to changes in $\mathrm{Mdm} 2$ protein levels. Small amounts of Mdm2 should then be sufficient for maintenance of overall p53 levels but would lead to increased p53 response, while only a near or complete loss of Mdm2 would result in overall accumulation of p53 protein. Figure 1 depicts possible outcomes for p53 activity arising from having different amounts of Mdm2 in cells.

An alternative explanation for the phenotypes observed in mice expressing a hypomorphic allele of $m d m 2$ is that the reduction in the levels of $\mathrm{Mdm} 2$ activates secondary pathways for p53 degradation. Additional ubiquitin ligases for p53 have been described including Cop1 (Dornan et al. 2004) and Pirh2 (Leng et al. 2003) and, although each is a p53 transcriptional target, neither has been shown to inhibit p53-mediated transcription. It is formally possible that when Mdm2 levels are subphysiologically low, these other E3 ligases can maintain the amount of p53 at its normal level as a part of some failsafe mechanism to maintain proliferative capability by the cells. However, since these E3s are not capable of directly suppressing p53 transcription, this would result in elevated p53 activity without altering the apparent p53 protein amounts. It would therefore be of interest to assess the relative levels and activity of other p53-specific E3s in the Mdm2 hypomorphic animals.

Overall the result that even modest reduction in the levels of $\mathrm{Mdm} 2$ provides a highly significant protection from cancer in this experimental setting strongly supports the notion that pharmacological disruption of Mdm2 and p53 can have therapeutic benefits in cancer patients.

\section{A price to be paid by having too much $M d m 2$}

Just as reducing Mdm2 levels results in increased p53 function and tumor suppression in mice, the converse seems also to be true. Targeted overexpression of $\mathrm{Mdm} 2$ in mammary epithelium leads to increased cellular hypertrophy and nuclear abnormalities as well as an increase in tumor formation (albeit at low penetrance), further supporting the idea that elevated Mdm2 expression even in the context of wild-type p53 can positively affect tumor progression (Lundgren et al. 1997). Furthermore, mice expressing extra copies of the $\mathrm{Mdm} 2$ gene under the control of its endogenous promoter are significantly predisposed to tumor formation, and this correlates with the finding that extra Mdm2 down-regulates the antiproliferative tumor-suppressor functions of p53 (Jones et al. 1998).

The amount of $\mathrm{Mdm} 2$ in cells and tissues can have profound effects in humans as well as in mice. The earliest findings about human $\mathrm{Mdm} 2$ were that $m d m 2$ gene amplification is not uncommon in some forms of cancer such as gliomas and sarcomas and is linked to poor clinical prognosis in patients (Oliner et al. 1992; CordonCardo et al. 1994; Onel and Cordon-Cardo 2004). However, it was also known that gene amplification is not the only explanation for overexpression of $\mathrm{Mdm} 2$, and the reasons for the enhanced expression of $\mathrm{Mdm} 2$ in tu- 


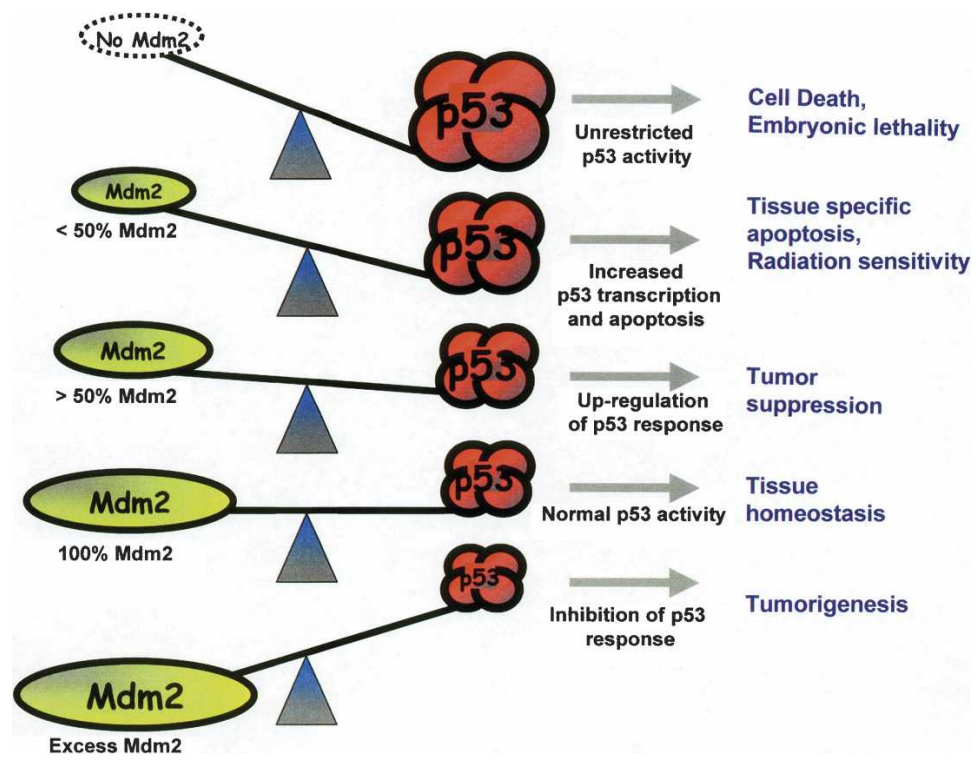

Figure 1. Tipping the p53-Mdm2 balance. The overall levels of $\mathrm{Mdm} 2$ in the cell greatly modify the activity of p53 in the in vivo systems highlighted in this review. Reduction of Mdm2 levels to $<50 \%$ leads to increased tissue-specific apoptosis, while a small reduction of $\mathrm{Mdm} 2$ to $80 \%$ of wild-type levels enhances tumor suppression without any adverse effects. Multiple lines of evidence suggest that increased Mdm2 levels though gene amplification or the GG version of SNP309 in the $m d m 2$ promoter increase abnormal proliferation and restrict p53 function. mors lacking gene amplification were poorly understood until recently. A landmark study from the group of A. Levine has shed new light on the mechanism of Mdm2 overexpression in some hereditary and sporadic tumors (Bond et al. 2004). Their group identified the existence of a single nucleotide polymorphism (SNP) in the Mdm2 promoter region (either a $\mathrm{T}$ or a $\mathrm{G}$ at -309 ), the $\mathrm{G}$ version of which confers enhanced Sp1-mediated transcription of Mdm2 mRNA (Bond et al. 2004). The homozygous GG version of SNP309 (found in 11\% of the population) in the $\mathrm{Mdm} 2$ promoter results in both markedly elevated Mdm2 expression levels and an earlier onset of both hereditary (in Li-Fraumeni patients) and sporadic tumors in the human population. The increased Mdm 2 protein levels in homozygous GG human cells are well correlated with reduced p53 activity. Thus the findings of Bond et al. (2004) fall in line with conclusions from the hypomorphic mouse described by Mendrysa et al. (2003, 2006) and show that Mdm2 is central for regulation of p53 not only in development but in adult, terminally differentiated human tissues. It is particularly worth mentioning that the increased levels of $\mathrm{Mdm} 2$ associated with the presence of SNP309 do not correlate well with reduced p53 protein levels (Avra et al. 2005). In fact, p53 in the GG cells can still be stabilized by DNA damage (albeit to a somewhat lesser extent than in TT cells) and is competent for DNA binding in vitro and to the p53-responsive element of some p53 target genes in vivo. As in the case with the hypomorphic $m d m 2$ mice where the levels of p53 protein are not higher than normal, results with the GG Mdm2 cells indicate that modulation of $\mathrm{Mdm} 2$ protein levels may primarily regulate p53 transcriptional activity while having a more subtle effect on $\mathrm{p} 53$ protein levels.

\section{A little more p53 will also do the trick}

The current paradigm would predict that overexpression of $\mathrm{Mdm} 2$ or mutations in p53 protein are two reciprocal mechanisms for tumor progression. Although this would suggest that they should lead to a similar clinical outcome, this is not supported by results with patients in the clinic. Indeed, there is significant variability in the prognosis associated with either $\mathrm{Mdm} 2$ overexpression or p53 mutations (Onel and Cordon-Cardo 2004). As discussed above, raising or lowering Mdm2 can impact p53 activity and tumorigenesis. What about altering p53 levels? Garcia-Cao et al. (2002) attempted to ask this by using the reciprocal approach of elevating the wild-type p53 gene dosage in mice. They generated transgenic mice with an extra copy of the p53 allele in the context of two wild-type alleles already present in the animals by introducing a large genomic segment spanning the endogenous p53 locus. The resulting mice were phenotypically indistinguishable from wild-type animals although they exhibited enhanced tumor resistance and apoptotic response to DNA damage. It is remarkable that, just like the hypomorphic $m d m 2$ mice, the resting levels of p53 protein in the fibroblasts (MEFs) from the mice generated by Garcia-Cao et al. were not affected and that p53 did not accumulate to higher levels than in wild-type animals following DNA damage. Their data pose the interesting question as to how p53 in these animals is more active yet not more abundant. Although Garcia-Cao et al. did not show data with Mdm2, based on the findings with the hypomorphic mdm2 mice, it is possible that the levels of $\mathrm{Mdm} 2$ in these animals, while adequate to degrade the extra p53, are not sufficient to completely down-regulate p53 activity resulting from DNA damage.

Although the existence of alternative p53 E3 ligases might be relevant to findings with the hypomorphic mdm2 mice, this does not necessarily explain why mice with an extra p53 allele fail to accumulate excess p53 and yet their p53 is superactive. Here we propose another scenario. In such mice, elevated levels of p53 might well produce increased amounts of its target, Mdm2. A higher amount of $\mathrm{Mdm} 2$ would both degrade the extra p53 protein and also the other negative regulator of p53, MdmX 
(Chen et al. 2005; Okamoto et al. 2005; Pereg et al. 2005), thus bringing $\mathrm{p} 53$ down to levels found in wild-type cells, but such p53 would be relatively more active due to the reduced amount of MdmX. We look forward to future reports on the levels of Mdm2 and MdmX in cells from mice with three $p 53$ alleles.

\section{p53, Mdm2, and the aging question}

In 2002 an unanticipated set of observations from Donehower's laboratory led to the conclusion that having a "superactive" p53 might simultaneously reduce tumor incidence and yet increase premature aging (Tyner et al. 2002). The mice they had generated occurred somewhat accidentally - the investigators' original intent was to generate knock-in mice expressing a tumor-derived mutant p53. Instead, the resulting mice expressed a truncated form of p53 encoding exons 7-11 but lacking exons $1-6$ and likely initiating at codon 243 , along with a single wild-type allele of $\mathrm{p} 53$. The resulting $\left(\mathrm{p} 53^{+/ \mathrm{m}}\right)$ animals died prematurely (96 wk vs. 118 wk for wild-type animals) and displayed several characteristics of premature aging. They had pronounced osteoporosis, lymphoid atrophy, lordokyphosis, and many other symptoms of advanced aging. Strikingly, the $\mathrm{p} 53^{+/ \mathrm{m}}$ mice had acquired significantly fewer sporadic tumors than their wild-type counterparts $\left(27 / 56\right.$ in wild-type mice vs. $2 / 35$ in $\mathrm{p} 53^{+/ \mathrm{m}}$ mice) by the time of their death. Furthermore, MEFs from the $\mathrm{p} 53^{+/ \mathrm{m}}$ mice had significantly reduced numbers of transformed foci resulting from overexpressed Ras plus Myc when compared with wild-type MEFs, and this combination of p53 alleles, when ectopically expressed in p53-null Saos-2 cells, exhibited enhanced transcriptional activity (cf. wild-type p53 alone) in a reporter assay. The authors suggested that the presence of the mutant p53 allele activates the other wild-type allele in the mice. It should be noted, however, that the $\mathrm{p} 53^{+/ \mathrm{m}}$ mice also have a significant deletion in the vicinity of the $p 53$ locus that could have contributed to the striking phenotype of these mice (Gentry and Venkatachalam 2005). Nevertheless, another set of mice that displayed similar advanced aging argues that the results seen by Tyner et al. stemmed from the combination of $p 53$ alleles harbored by their mice.

Scrable and colleagues (Maier et al. 2004) generated transgenic mouse strains that express ectopically a naturally occurring $\mathrm{N}$-terminally truncated form of p53 (p44) (Courtois et al. 2002; Yin et al. 2002) along with wildtype p53. In fact, it is now known that, like its p63 and p73 homologs, p53 can be expressed as multiple isoforms (including $\mathrm{p} 44$ ) with different $\mathrm{N}$ and $\mathrm{C}$ termini that are likely to have different activities and interactions (Bourdon et al. 2005; Mills 2005; Prives and Manfredi 2005; Rohaly et al. 2005). The p44 transgenic mice display the same striking phenotype of accelerated and pronounced aging as did the $\mathrm{p} 53^{+/ \mathrm{m}}$ mice in the Donehower study (Tyner et al. 2002). Maier et al. (2004) took their observation further when they examined several p53 targets in the $\mathrm{p} 44$ mice. They showed that $\mathrm{p} 21, \mathrm{Mdm} 2$, and IGFBP3 RNAs are increased in the p44 mice, supporting the as- sumption that premature aging requires a superactive version of p53. Nevertheless, at least one other known p53 target was not overexpressed-there was little or no difference in Gadd45 RNA levels between wild-type and p44 transgenic mice. Interestingly, the p44 mice also possess hyperactivated insulin-like growth factor (IGF) signaling, evidenced by increased phosphorylated AKT and Forkhead (FKHR), and decreased active PTEN. Cells from these mice also display sustained ERK activation and high levels of Ras. These effects are consistent with conditions leading to senescence, and it was found that treatment of MEFs from the p44 mice with the ERK inhibitor U0126 reduces the appearance of senescent cells. There is at present a fairly strong connection between cellular senescence and aging in animals (Campisi 2005), and thus the data in the Scrable study (Maier et al. 2004) have provided significant insight into the premature aging phenotype of mice containing both full-length and truncated p53 proteins.

Given the findings suggesting that at least partially hyperactivated p53 can promote aging, it is of considerable interest to determine whether the activated p53 found in mice expressing the hypomorphic allele of mdm2 or mice with an extra $p 53$ gene would also similarly display the premature aging characteristics. In fact, in neither case was there any evidence of early aging. Mendrysa et al. $(2003,2006)$ observed no significant changes in either the life span of the mice or any significant differences from wild-type animals in aging phenotypes such as reduced dermal thickness and reduction in subcutaneous fat and osteoporosis. Even their mice with a $70 \%$ reduction in $\mathrm{Mdm} 2$ did not display any of these characteristics. Similarly, the extra p53 allele mice of Garcia-Cao et al. did not display noticeable premature aging phenotypes.

Why do mice with reduced Mdm2 or an additional p53 allele fail to age prematurely while the mice generated in the laboratories of Donehower (Tyner et al. 2002) and Scrable (Maier et al. 2004) display this extraordinary phenotype? In each of the above cases, the p53 appears to be superactive, and its heightened activity is believed to cause the premature aging outcome. We can point to one key difference between these two sets of mice. In one case (the hypomorphic $m d m 2$ allele and extra $p 53$ allele mice), the normal ratio of the different p53 isoforms is very likely to be maintained, while in the second case (the $\mathrm{p} 53^{+/ \mathrm{m}}$ and $\mathrm{p} 44$ transgenic mice), that ratio has been significantly altered such that there is an isoform lacking the $\mathrm{N}$-terminal portion of $\mathrm{p} 53$ that is present at supraphysiological levels (even though Tyner et al. [2002] could detect the mRNA but not the truncated protein in cells from their mice, this is still formally true). Importantly as well, the data from Maier et al. (2004) clearly indicate that when $\mathrm{p} 44$ is present, some but not all p53 targets are more actively expressed. We therefore speculate that in aging mice, it is the imbalance between different p53 target genes that is required for their phenotype rather than an overall more active p53 and that the p53 in these mice should be considered as having an altered transcriptional program rather then an overall in- 
crease in activity. It would be predicted that the alterations in IGF signaling or senescence-related characteristics would not be seen in either the hypomorphic $m d m 2$ or extra $p 53$ mice, and this would be of interest to determine. It will be also be of great importance to gain more mechanistic insight into the cellular and organismal response to having full-length and truncated p53 proteins expressed and more generally to acquire insight into the roles played by the different p53 isoforms in cells, animals, and development. We look forward to future research that addresses these issues.

\section{Translating lessons from mice into Mdm2-targeted therapeutics}

Mice with either an extra allele of wild-type $p 53$ or with lowered Mdm2 expression lack the severe adverse effects that are associated with either loss of cellularity due to arrest or death or premature aging of the animals. This is of great potential importance, particularly since both sets of animals have acquired significant cancer resistance. As development and description of new compounds for up-regulation of p53 activity are ongoing in several laboratories, the work of Mendrysa et al. (2003, 2006) indicates that the focus on $\mathrm{Mdm} 2$ as a therapeutic target may prove to be very fruitful. The concern that uncoupling of the p53-Mdm2 circuit would lead to unrestricted p53 function and widespread cell death is largely allayed by their results.

The remarkable fact that the $\mathrm{Mdm} 2-\mathrm{p} 53$ interaction is mediated by three hydrophobic residues (Kussie et al. 1996) suggested that Mdm2 might be a suitable target for small compounds that could uncouple p53 and Mdm2, leading to elevation in p53 activity (Moll and Zaika 2000; Vassilev 2004). In general, protein-protein interactions are viewed as poor targets for drug design due to the fact that protein complexes usually have large interacting surfaces not easily disturbed by small molecules (Arkin and Wells 2004). Indeed, many inhibitors of the Mdm2-p53 interaction have been described, including short peptides and small pharmacological compounds (Bottger et al. 1997; Garcia-Echeverria et al. 2000; Duncan et al. 2001; Stoll et al. 2001; Fasan et al. 2004). Screens for novel peptides that can bind $\mathrm{Mdm} 2$ derived from phage display allowed for isolation of the "IPS peptide" that displayed 30-fold higher affinity than the native p53 peptide (Bottger et al. 1996). Alignment of the peptides also revealed the consensus sequence for binding to Mdm2 (PxFxDYWxxL) (Bottger et al. 1996, 1997). Permutations of the IPS peptide by increasing the hydrophobic content and the introduction of artificial amino acids led to the production of the "AP peptide." The AP peptide has a 2000-fold greater affinity for Mdm2 than the native p53 peptide (Garcia-Echeverria et al. 2000; Schon et al. 2004).

Additional pharmacological small molecule inhibitors of the $\mathrm{Mdm} 2 / \mathrm{p} 53$ interaction have also been described. First of these were the chalcones, which unfortunately can only inhibit the Mdm2-p53 interaction with IC50 values in the high micromolar range and have other off- target effects (Stoll et al. 2001; Kumar et al. 2003). Chlorofusin, a fungal cyclic nona-peptide was also identified as an Mdm2-p53-complex-disrupting compound. However, with a Kd of $4.6 \mu \mathrm{M}$ and a complex chemical structure, this reagent did not serve as a candidate drug with clinical implications (Duncan et al. 2001, 2003).

Recently two very promising small molecule antagonists of the Mdm2-p53 interaction were published. Vassiliev et al. (2004) identified several cis-imidazoline derivatives, dubbed the Nutlins. These compounds bind tightly to the $\mathrm{p} 53$ pocket of $\mathrm{Mdm} 2$ and displace $\mathrm{p} 53$ from the complex in vitro with an IC50 in the 100-300 nM range. Nutlins are cell permeable and able to inhibit Mdm2-p53 complex formation, stabilizing p53 and elevating the levels of p53-mediated transcription in tumor-derived cell lines with wild-type p53. Furthermore, Nutlins can suppress growth of established tumor xenographs in nude mice to the same extent as treatment with doxorubicin (Vassilev et al. 2004). Recently it was demonstrated that Nutlins increase p53 transcriptional activity in the absence of phosphorylation of key residues (Thompson et al. 2004).

RITA is another compound that has been recently described as a potent cell-membrane-permeable inhibitor of the Mdm2-p53 interaction. Unlike Nutlins, which were designed to bind to $\mathrm{Mdm} 2$ and competitively inhibit its binding to p53, RITA was identified from a screen of compounds capable of suppressing the growth of tumor cells in a p53-dependent manner (Issaeva et al. 2004). RITA binds to the $\mathrm{N}$ terminus of $\mathrm{p} 53$, thereby disrupting the Mdm2-p53 interaction, and leads to the accumulation of transcriptionally active p53. Perhaps the most surprising finding about this compound is that it is capable of activating the apoptosis-inducing function of p53 in tumor-derived but not in normal, untransformed cells. These results also support earlier observations that the activity of the p53 pathway may be differentially controlled in normal and tumor cells (Baker et al. 1990; D'Orazi et al. 2000).

Yet another pharmacological approach to uncoupling the Mdm2-p53 network has focused on the inhibition of the E3 ubiquitin ligase activity of Mdm2. Lai et al. (2002) identified a series of compounds able to differentiate between the Mdm2-mediated p53 ubiquitination and autoubiquitination activity of $\mathrm{Mdm} 2$. They identified three noncompetitive inhibitors of Mdm2-mediated p53 ubiquitination. All demonstrate an IC50 in the low micromolar range, and show no detectible effect on other E3s or on Mdm2 autoubiquitination (Lai et al. 2002). While this work was done in an in vitro system, pharmacological optimization of these compounds may lead to new chemotherapeutic agents targeting the Mdm2p53 network.

Very recently, another set of inhibitors of Mdm2 ubiquitin ligase activity has been identified (Yang et al. 2005). These molecules exhibit considerable specificity for $\mathrm{Mdm} 2$ and are cell membrane permeable; however, they still show some p53-independent toxicity in cells as well as lack of specificity at higher concentrations in vitro.

The results with the hypomorphic $m d m 2$ mice are 
heartening in that even a modest reduction in overall levels of Mdm2 leads to increased p53 activity without such negative effects. Drugs targeting dissociation of the Mdm2-p53 complex would not have to efficiently disrupt their interaction, as even a modest release of p53 should prove to be effective in conjunction with radiation therapy. Furthermore, a relatively small reduction in Mdm2-p53 association is not likely to be associated with detrimental side-effects for the patient. Note, however, that the results of Mendrysa et al. (2003) imply that there might be a lesser chance of success with drugs that target Mdm2 E3 activity because they would need to accomplish virtually complete ablation of Mdm2 function with high specificity. One other promising approach may be to target the Mdm2 ATP-binding function, which facilitates nucleolar localization of $\mathrm{Mdm} 2$, and requires an intact RING domain, which is also essential for the E3 activity (Poyurovsky et al. 2003). Thus, compounds with specificity for $\mathrm{Mdm} 2$ nucleotide binding could be effective in physically segregating $\mathrm{Mdm} 2$ and p53.

In summary, current work using mouse model systems where the levels of Mdm2 and the activity of p53 may be modulated has provided new and important insight into the possible outcomes of drug discovery programs that target these two proteins for cancer therapy. These findings seem to suggest a likely positive outcome for either the introduction into animals or human patients of ectopic p53 or, what is perhaps more attainable, targeted reduction of $\mathrm{Mdm} 2$ activity prior to therapy.

\section{References}

Arkin, M.R. and Wells, J.A. 2004. Small-molecule inhibitors of protein-protein interactions: Progressing towards the dream. Nat. Rev. Drug Discov. 3: 301-317.

Arva, N.C., Gopen, T.R., Talbott, K.E., Campbell, L.E., Chicas, A., White, D.E., Bond, G.L., Levine, A.J., and Bargonetti, J. 2005. A chromatin-associated and transcriptionally inactive p53-Mdm2 complex occurs in mdm2 SNP309 homozygous cells. J. Biol. Chem. 280: 26776-26787.

Baker, S.J., Markowitz, S., Fearon, E.R., Willson, J.K., and Vogelstein, B. 1990. Suppression of human colorectal carcinoma cell growth by wild-type p53. Science 249: 912-915.

Bond, G.L., Hu, W., Bond, E.E., Robins, H., Lutzker, S.G., Arva, N.C., Bargonetti, J., Bartel, F., Taubert, H., Wuerl, P., et al. 2004. A single nucleotide polymorphism in the MDM2 promoter attenuates the p53 tumor suppressor pathway and accelerates tumor formation in humans. Cell 119: 591-602.

Bottger, V., Bottger, A., Howard, S.F., Picksley, S.M., Chene, P., Garcia-Echeverria, C., Hochkeppel, H.K., and Lane, D.P. 1996. Identification of novel mdm2 binding peptides by phage display. Oncogene 13: 2141-2417.

Bottger, A., Bottger, V., Sparks, A., Liu, W.L., Howard, S.F., and Lane, D.P. 1997. Design of a synthetic Mdm2-binding mini protein that activates the p53 response in vivo. Curr. Biol. 7: 860-869.

Bourdon, J.C., Fernandes, K., Murray-Zmijewski, F., Liu, G., Diot, A., Xirodimas, D.P., Saville, M.K., and Lane, D.P. 2005. p53 isoforms can regulate p53 transcriptional activity. Genes \& Dev. 19: 2122-2137.

Campisi, J. 2005. Senescent cells, tumor suppression, and or- ganismal aging: Good citizens, bad neighbors. Cell 120: 513 522.

Chen, L., Gilkes, D.M., Pan, Y., Lane, W.S., and Chen, J. 2005. ATM and Chk2-dependent phosphorylation of MDMX contribute to p53 activation after DNA damage. $E M B O ~ J .24:$ 3411-3422.

Cordon-Cardo, C., Latres, E., Drobnjak, M., Oliva, M.R., Pollack, D., Woodruff, J.M., Marechal, V., Chen, J., Brennan, M.F., and Levine, A.J. 1994. Molecular abnormalities of mdm2 and $\mathrm{p} 53$ genes in adult soft tissue sarcomas. Cancer Res. 54: 794-799.

Courtois, S., Verhaegh, G., North, S., Luciani, M.G., Lassus, P., Hibner, U., Oren, M., and Hainaut, P. 2002. $\Delta$ N-p53, a natural isoform of p53 lacking the first transactivation domain, counteracts growth suppression by wild-type p53. Oncogene 21: 6722-6728.

D’Orazi, G., Marchetti, A., Crescenzi, M., Coen, S., Sacchi, A., and Soddu, S. 2000. Exogenous wt-p53 protein is active in transformed cells but not in their non-transformed counterparts: Implications for cancer gene therapy without tumor targeting. J. Gene Med. 2: 11-21.

Dornan, D., Wertz, I., Shimizu, H., Arnott, D., Frantz, G.D., Dowd, P., O'Rourke, K., Koeppen, H., and Dixit, V.M. 2004. The ubiquitin ligase COP1 is a critical negative regulator of p53. Nature 429: 86-92.

Duncan, S.J., Gruschow, S., Williams, D.H., McNicholas, C., Purewal, R., Hajek, M., Gerlitz, M., Martin, S., Wrigley, S.K., and Moore, M. 2001. Isolation and structure elucidation of Chlorofusin, a novel p53-MDM2 antagonist from a Fusarium sp. J. Am. Chem. Soc. 123: 554-560.

Duncan, S.J., Cooper, M.A., and Williams, D.H. 2003. Binding of an inhibitor of the p53/MDM2 interaction to MDM2. Chem. Commun. (Camb.) 316-317.

Fasan, R., Dias, R.L., Moehle, K., Zerbe, O., Vrijbloed, J.W., Obrecht, D., and Robinson, J.A. 2004. Using a $\beta$-hairpin to mimic an $\alpha$-helix: Cyclic peptidomimetic inhibitors of the p53-HDM2 protein-protein interaction. Angew Chem. Int. Ed. Engl. 43: 2109-2112.

Garcia-Cao, I., Garcia-Cao, M., Martin-Caballero, J., Criado, L.M., Klatt, P., Flores, J.M., Weill, J.C., Blasco, M.A., and Serrano, M. 2002. "Super p53" mice exhibit enhanced DNA damage response, are tumor resistant and age normally. EMBO J. 21: 6225-6235.

Garcia-Echeverria, C., Chene, P, Blommers, M.J., and Furet, P. 2000. Discovery of potent antagonists of the interaction between human double minute 2 and tumor suppressor p53. J. Med. Chem. 43: 3205-3208.

Gentry, A. and Venkatachalam, S. 2005. Complicating the role of p53 in aging. Aging Cell 4: 157-160.

Issaeva, N., Bozko, P., Enge, M., Protopopova, M., Verhoef, L.G., Masucci, M., Pramanik, A., and Selivanova, G. 2004. Small molecule RITA binds to p53, blocks p53-HDM-2 interaction and activates p53 function in tumors. Nat. Med. 10: 13211328.

Iwakuma, T. and Lozano, G. 2003. MDM2, an introduction. Mol. Cancer Res. 1: 993-1000.

Jones, S.N., Roe, A.E., Donehower, L.A., and Bradley, A. 1995. Rescue of embryonic lethality in Mdm2-deficient mice by absence of p53. Nature 378: 206-208.

Jones, S.N., Hancock, A.R., Vogel, H., Donehower, L.A., and Bradley, A. 1998. Overexpression of Mdm2 in mice reveals a p53-independent role for $\mathrm{Mdm} 2$ in tumorigenesis. Proc. Nat1. Acad. Sci. 95: 15608-15612.

Kumar, S.K., Hager, E., Pettit, C., Gurulingappa, H., Davidson, N.E., and Khan, S.R. 2003. Design, synthesis, and evaluation of novel boronic-chalcone derivatives as antitumor agents. J. 
Med. Chem. 46: 2813-2815.

Kussie, P.H., Gorina, S., Marechal, V., Elenbaas, B., Moreau, J., Levine, A.J., and Pavletich, N.P. 1996. Structure of the MDM2 oncoprotein bound to the p53 tumor suppressor transactivation domain. Science 274: 948-953.

Lai, Z., Yang, T., Kim, Y.B., Sielecki, T.M., Diamond, M.A., Strack, P., Rolfe, M., Caligiuri, M., Benfield, P.A., Auger, K.R., et al. 2002. Differentiation of Hdm2-mediated p53 ubiquitination and $\mathrm{Hdm} 2$ autoubiquitination activity by small molecular weight inhibitors. Proc. Natl. Acad. Sci. 99: 14734-14739.

Leng, R.P., Lin, Y., Ma, W., Wu, H., Lemmers, B., Chung, S., Parant, J.M., Lozano, G., Hakem, R., and Benchimol, S. 2003. Pirh2, a p53-induced ubiquitin-protein ligase, promotes p53 degradation. Cell 112: 779-791.

Lundgren, K., Montes de Oca Luna, R., McNeill, Y.B., Emerick, E.P., Spencer, B., Barfield, C.R., Lozano, G., Rosenberg, M.P., and Finlay, C.A. 1997. Targeted expression of MDM2 uncouples $S$ phase from mitosis and inhibits mammary gland development independent of p53. Genes \& Dev. 11:714725.

Maier, B., Gluba, W., Bernier, B., Turner, T., Mohammad, K., Guise, T., Sutherland, A., Thorner, M., and Scrable, H. 2004. Modulation of mammalian life span by the short isoform of p53. Genes \& Dev. 18: 306-319.

Marine, J.C. and Jochemsen, A.G. 2005. Mdmx as an essential regulator of p53 activity. Biochem. Biophys. Res. Commun. 331: 750-760.

Mendrysa, S.M., McElwee, M.K., Michalowski, J., O'Leary, K.A., Young, K.M., and Perry, M.E. 2003. $\mathrm{mdm} 2$ is critical for inhibition of p53 during lymphopoiesis and the response to ionizing irradiation. Mol. Cell. Biol. 23: 462-472.

Mendrysa, S.M., O’Leary, K.A., McElwee, M.K., Michalowski, J., Eisenman, R.N., Powell, D.A., and Perry, M.E. 2006. Tumor suppression and normal aging in mice with constitutively high p53 activity. Genes \& Dev. 20: 16-21.

Migliorini, D., Denchi, E.L., Danovi, D., AJochemsen, A., Capillo, M., Gobbi, A., Helin, K., Pelicci, P.G., and Marine, J.C. 2002. Mdm4 (Mdmx) regulates p53-induced growth arrest and neuronal cell death during early embryonic mouse development. Mol. Cell. Biol. 22: 5527-5538.

Mills, A.A. 2005. p53: Link to the past, bridge to the future. Genes \& Dev. 19: 2091-2099.

Moll, U.M. and Zaika, A. 2000. Disrupting the p53-mdm2 interaction as a potential therapeutic modality. Drug Resist. Updat. 3: 217-221.

Momand, J., Wu, H.H., and Dasgupta, G. 2000. MDM2-Master regulator of the p53 tumor suppressor protein. Gene 242: 1529 .

Montes de Oca Luna, R., Wagner, D.S., and Lozano, G. 1995. Rescue of early embryonic lethality in mdm2-deficient mice by deletion of p53. Nature 378: 203-206.

Okamoto, K., Kashima, K., Pereg, Y., Ishida, M., Yamazaki, S., Nota, A., Teunisse, A., Migliorini, D., Kitabayashi, I., Marine, J.C., et al. 2005. DNA damage-induced phosphorylation of MdmX at serine 367 activates p53 by targeting MdmX for Mdm2-dependent degradation. Mol. Cell. Biol. 25: 9608-9620.

Oliner, J.D., Kinzler, K.W., Meltzer, P.S., George, D.L., and Vogelstein, B. 1992. Amplification of a gene encoding a p53associated protein in human sarcomas. Nature 358: 80-83.

Onel, K. and Cordon-Cardo, C. 2004. MDM2 and prognosis. Mol. Cancer Res. 2: 1-8.

Parant, J., Chavez-Reyes, A., Little, N.A., Yan, W., Reinke, V., Jochemsen, A.G., and Lozano, G. 2001. Rescue of embryonic lethality in Mdm4-null mice by loss of Trp53 suggests a nonoverlapping pathway with MDM2 to regulate p53. Nat.
Genet. 29: 92-95.

Pereg, Y., Shkedy, D., de Graaf, P., Meulmeester, E., delsonAverbukh, M., Salek, M., Biton, S., Teunisse, A.F., Lehmann, W.D., Jochemsen, A.G., et al. 2005. Phosphorylation of Hdmx mediates its Hdm2- and ATM-dependent degradation in response to DNA damage. Proc. Natl. Acad. Sci. 102: 5056-5061.

Poyurovsky, M.V., Jacq, X., Ma, C., Karni-Schmidt, O., Parker, P.J., Chalfie, M., Manley, J.L., and Prives, C. 2003. Nucleotide binding by the Mdm2 RING domain facilitates Arf-independent Mdm2 nucleolar localization. Mol. Cell 12: 875887.

Prives, C. and Hall, P.A. 1999. The p53 pathway. J. Pathol. 187: 112-126.

Prives, C. and Manfredi, J.J. 2005. The continuing saga of p53More sleepless nights ahead. Mol. Cell 19: 719-721.

Rohaly, G., Chemnitz, J., Dehde, S., Nunez, A.M., Heukeshoven, J., Deppert, W., and Dornreiter, I. 2005. A novel human p53 isoform is an essential element of the ATR-intra-S phase checkpoint. Cell 122: 21-32.

Schon, O., Friedler, A., Freund, S., and Fersht, A.R. 2004. Binding of p53-derived ligands to MDM2 induces a variety of long range conformational changes. J. Mol. Biol. 336: 197-202.

Stoll, R., Renner, C., Hansen, S., Palme, S., Klein, C., Belling, A., Zeslawski, W., Kamionka, M., Rehm, T., Muhlhahn, P., et al. 2001. Chalcone derivatives antagonize interactions between the human oncoprotein MDM2 and p53. Biochemistry 40: 336-344.

Thompson, T., Tovar, C., Yang, H., Carvajal, D., Vu, B.T., Xu, Q., Wahl, G.M., Heimbrook, D.C., and Vassilev, L.T. 2004. Phosphorylation of p53 on key serines is dispensable for transcriptional activation and apoptosis. J. Biol. Chem. 279: 53015-53022.

Tyner, S.D., Venkatachalam, S., Choi, J., Jones, S., Ghebranious, N., Igelmann, H., Lu, X., Soron, G., Cooper, B., Brayton, C., et al. 2002. p53 mutant mice that display early ageing-associated phenotypes. Nature 415: 45-53.

Vassilev, L.T. 2004. Small-molecule antagonists of p53-MDM2 binding: Research tools and potential therapeutics. Cell Cycle 3: 419-421.

Vassilev, L.T., Vu, B.T., Graves, B., Carvajal, D., Podlaski, F., Filipovic, Z., Kong, N., Kammlott, U., Lukacs, C., Klein, C., et al. 2004. In vivo activation of the p53 pathway by smallmolecule antagonists of MDM2. Science 303: 844-848.

Vousden, K.H. and Lu, X. 2002. Live or let die: The cell's response to p53. Nat. Rev. Cancer 2: 594-604.

Vousden, K.H. and Prives, C. 2005. p53 and prognosis: New insights and further complexity. Cell 120: 7-10.

Yang, Y., Ludwig, R.L., Jensen, J.P., Pierre, S.A., Medaglia, M.V., Davydov, I.V., Safiran, Y.J., Oberoi, P., Kenten, J.H., Phillips, A.C., Weissman, A.M., and Vousden, K.H. 2005. Small molecule inhibitors of HDM2 ubiquitin ligase activity stabilize and activate p53 in cells. Cancer Cell 7: 547-559.

Yin, Y., Stephen, C.W., Luciani, M.G., and Fahraeus, R. 2002. p53 Stability and activity is regulated by Mdm2-mediated induction of alternative p53 translation products. Nat. Cell Biol. 4: 462-467. 


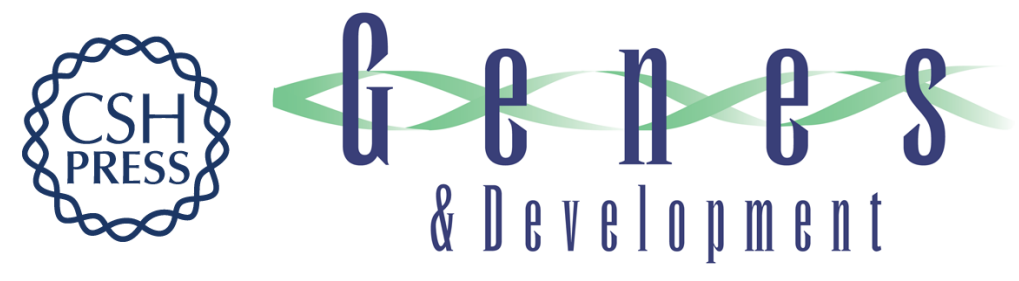

\section{Unleashing the power of p53: lessons from mice and men}

Masha V. Poyurovsky and Carol Prives

Genes Dev. 2006, 20:

Access the most recent version at doi:10.1101/gad.1397506

Related Content Tumor suppression and normal aging in mice with constitutively high p53 activity Susan M. Mendrysa, Kathleen A. O'Leary, Matthew K. McElwee, et al. Genes Dev. January , 2006 20: 16-21

References This article cites 55 articles, 20 of which can be accessed free at: http://genesdev.cshlp.org/content/20/2/125.full.html\#ref-list-1

Articles cited in:

http://genesdev.cshlp.org/content/20/2/125.full.html\#related-urls

\section{License}

Email Alerting

Receive free email alerts when new articles cite this article - sign up in the box at the top Service right corner of the article or click here.

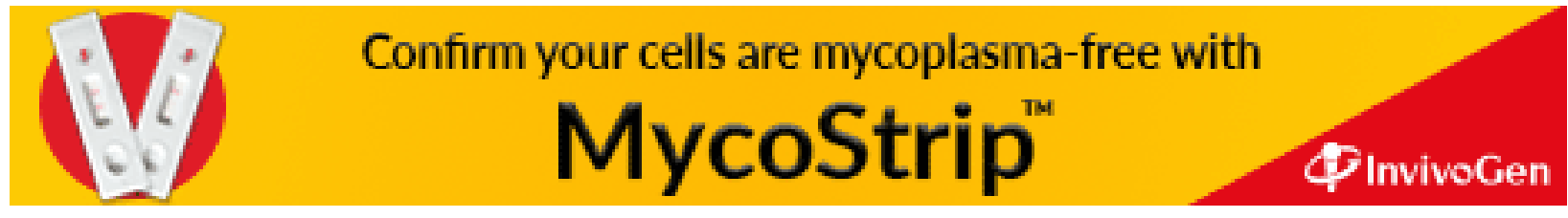

